\title{
FUNCTIONAL ASSAY, EXPRESSION OF GROWTH FACTORS AND PROTEINS MODULATING BONE-ARRANGEMENT IN HUMAN OSTEOBLASTS SEEDED ON AN ANORGANIC BOVINE BONE BIOMATERIAL
}

Oriana Trubiani ${ }^{*}$, Stefania Fulle ${ }^{2}$, Tonino Traini ${ }^{1}$, Maya Paludi ${ }^{1}$, Rita la Rovere ${ }^{2}$, Monia Orciani $^{3}$, Sergio Caputi ${ }^{1}$, and Adriano Piattelli'.

${ }^{1}$ Department of Oral Science, Nano and Biotechnology, ${ }^{2}$ Department of Basic and Applied Medical Sciences,
University of Chieti-Pescara (Italy),
${ }^{3}$ Department of Molecular Pathology and Innovative Therapies, Marche Polytechnic University, Ancona, Italy.

Abstract

The basic aspects of bone tissue engineering include chemical composition and geometry of the scaffold design, because it is very important to improve not only cell attachment and growth but especially osteodifferentiation, bone tissue formation, and vascularization. Geistlich Bio$\mathrm{Oss}^{\circledR}(\mathrm{GBO})$ is a xenograft consisting of deproteinized, sterilized bovine bone, chemically and physically identical to the mineral phase of human bone.

In this study, we investigated the growth behaviour and the ability to form focal adhesions on the substrate, using vinculin, a cytoskeletal protein, as a marker. Moreover, the expression of bone specific proteins and growth factors such as type I collagen, osteopontin, bone sialoprotein, bone morphogenetic protein-2 (BMP-2), BMP-7 and de novo synthesis of osteocalcin in normal human osteoblasts (NHOst) seeded on xenogenic GBO were evaluated. Our observations suggest that after four weeks of culture in differentiation medium, the NHOst showed a high affinity for the three dimensional biomaterial; in fact, cellular proliferation, migration and colonization were clearly evident. The osteogenic differentiation process, as demonstrated by morphological, histochemical, energy dispersive X-ray microanalysis and biochemical analysis was mostly obvious in the NHOst grown on threedimensional inorganic bovine bone biomaterial. Functional studies displayed a clear and significant response to calcitonin when the cells were differentiated. In addition, the presence of the biomaterial improved the response, suggesting that it could drive the differentiation of these cells towards a more differentiated osteogenic phenotype. These results encourage us to consider GBO an adequate biocompatible three-dimensional biomaterial, indicating its potential use for the development of tissue-engineering techniques.

Keywords: Dental, regenerative repair, osteoblasts, bone, biomaterials, osteoconduction/ osteoinduction, signalling molecules, growth factors.

*Address for correspondence:

Trubiani Oriana

Department of Oral Science Nano and Biotechnology,

University of Chieti-Pescara

Via Vestini 31

I-66100 Chieti, Italy

Telephone Number: +39/0871/3554097

FAX Number: +390871-3554070

E-mail: trubiani@unich.it

\section{Introduction}

In recent years, millions of devices made from diverse biocompatible materials have been implanted in humans. The progress in implant technology and tissue regeneration, and the interaction of cells or living tissues with the surface of different biomaterials are important in basic research as well as in clinical practice (Diener et al.,2005). To engineer living tissue in vitro, cultured cells are grown on bioactive degradable scaffolds that provide the physical and chemical stimulus to guide the differentiation of the cells and their assembly into threedimensional tissues (Griffith and Naughton, 2002).

The ideal biomaterial for a scaffold would selectively interact with the specific adhesion and growth factor receptors expressed by target cells in the surrounding tissues (Griffith and Naughton, 2002), and could guide migration of the target cells into the injury site and stimulate their growth and differentiation (Hubbell, 1999).

Bone growth and integration with the biomaterial used in medical devices is dependent on the recruitment, attachment, and differentiation of the cellular components that are essential for bone formation and development (AlSaffar and Revell, 2000). Bone formation involves the proliferation and differentiation of stromal cells along an osteogenic pathway that leads to the formation of osteoblasts; it is believed that the process of cellular differentiation is controlled by a cascade of molecular events involving a combination of genetic programming and gene regulation by hormones, cytokines, and bone associated-molecules (Sodek and Cheifetz, 2000).

Progression of osteogenic differentiation is currently best indicated by temporal expression of bone-related proteins, in particular: collagen type I, bone sialoprotein (BSP), osteopontin (OPN), bone morphogenetic proteins (BMPs), plasma-derived growth factor (PDGF)-A (Cowan et al., 2005), and osteocalcin, a small, noncollagenous and highly conserved, and secreted protein with significance in metabolic disease; all these proteins are secreted by osteoblasts and play a role in mineralization and calcium ion homeostasis (Lohmann et al., 2002).

Geistlich Bio-Oss (GBO) is a xenograft consisting of deproteinized, sterilized bovine bone with 75-80\% porosity and a crystal size of $\pm 10 \mu \mathrm{m}$ in the form of cortical granules; it has a natural, nonantigenic porous matrix, chemically and physically identical to the mineral phase of human bone. It has been reported to be highly osteoconductive and to show a very low resorption rate (Piattelli et al., 1999; Sartori et al., 2003; Jensen et al., 2006; Traini et al., 2007); moreover the bovine bone 
mineral apparently failed to be involved in further tissue remodelling (Traini et al., 2008, Araújo and Lindhe, 2009).

In previous human studies evaluating maxillary sinus augmentation after 6 months and 7 years, GBO has been demonstrated to be well integrated in the host tissues and to produce new bone with features similar to pre-existing osseous tissue (Orsini et al., 2005; Orsini et al., 2007) and in vitro is well qualified to be a substrate for cell seeding (Jensen et al., 2006; Acil et al., 2002). These results are in contrast with the data demonstrating that the proliferation rate of osteoblast-like cells seeded on GBO was lower respect to other biomaterials (Turhani et al., 2005; Wiedmann-Al-Ahmad et al., 2005; Schmitt et al., 2008). According with other authors (Wiedmann-Al-Ahmad et al., 2005) it is believed that one reason for these different results could be the source of the cells that could develop a different growth behaviour, and another reason could be the different culture conditions (e.g., seeding density, cultivation duration, medium of culture, inductive medium).

Actually, recent reports have indicated that the analysis of focal adhesion though the evaluation of cytoskeletal proteins, as vinculin and actin, could be a new and interesting tool for the study of biomimetic surfaces used in tissue engineering (Hench and Polak, 2002; Diener et al., 2005; Born et al., 2009).

The idea of this study was to elucidate in NHOst cells cultured in presence of GBO, the behaviour growth, the ability to form focal adhesions, the osteogenic differentiation process, the expression of growth factors and proteins, such as type I collagen, OPN, BSP, BMP-2, BMP-7 and osteocalcin, and in addition to assess the functional response to calcitonin (CT) and parathormone (PTH).

\section{Materials and Methods}

\section{Cell culture and osteogenic differentiation}

Commercially available primary human osteoblasts (NHOst) from both femur and tibia of different donor systems (Lonza Walkersville Inc, Walkersville, MD, USA) were grown in Osteoblast Growth Media (OBM) (Lonza). The phenotype of the cells was characterized by the expression levels of alkaline phosphatase (ALP), collagen type I, osteocalcin and CD44, and formation of mineralization nodules.

For osteogenesis induction the NHOst were maintained in culture for 24 hours in OGM basal medium at $37^{\circ} \mathrm{C}$, in a humidified atmosphere of $5 \% \mathrm{CO}_{2}$, allowing the cells to adhere on bone particles (Geistlich Bio-Oss ${ }^{\circledR}, \mathrm{GBO}$; Geistlich, Wohlhusen, Switzerland), previously washed overnight with the OBM medium. Subsequently, osteogenic differentiation was induced for a period of 4 weeks by the OGM medium (OBM basal medium supplemented with $200 \mathrm{nM}$ of hydrocortisone-21hemisuccinate and $7.5 \mathrm{mM}$ of $\beta$-glycerophosphate). Briefly, the cells were seeded at 5,000 cells $/ \mathrm{cm}^{2}$, the medium was changed every 3 to 4 days and at each medium change the culture was examined to be sure that the monolayer was intact. Confluent cells with and without GBO were induced to osteogenic differentiation with OGM medium and after 4 weeks of incubation the cells were stained with Alizarin Red to evaluate the progressive mineralization. Cells in the developing adherent layer were used for the experiments described below, after removal with $0.1 \%$ trypsin solution, and cell growth was evaluated by the Trypan Blue exclusion test. Cells were periodically checked under a phase contrast light microscope and finally analysed by scanning electron microscopy (SEM) and processed for biochemical analyses. All experiments were carried out using cells at the second passage and repeated with two different cell lines with similar results. Controls consisted of NHOst grown without xenogenic biomaterials.

\section{MTT assay}

The viability of NHOst cells seeded with or without GBO was measured by the quantitative colorimetric MTT (3[4,5-dimethyl-2-thiazolyl]-2,5-diphenyl-2 Htetrazoliumbromide test) (Promega, Milan, Italy). 5.000 cells/well were seeded into a 96-well culture plate with OBM medium, after $24 \mathrm{~h}$ of incubation at $37^{\circ} \mathrm{C}, 15 \mu \mathrm{l} /$ well of MTT was added to culture medium, and cells were incubated for $3 \mathrm{hrs}$ at $37^{\circ} \mathrm{C}$. The supernatants were read at $650 \mathrm{~nm}$ wavelength using an ND-1000 NanoDrop Spectrophotometer (NanoDrop Technologies, Rockland, DE, USA). The MTT assay was performed in four independent experiments, six replicate wells for each experimental point.

\section{Immunofluorescence staining and confocal laser scanning microscope analysis}

Cells grown on glass coverslips were fixed for $10 \mathrm{~min}$ at room temperature (RT) with $4 \%$ paraformaldehyde in $0.1 \mathrm{M}$ sodium phosphate buffer (PBS), pH 7.4. After washing in PBS, cultures were processed for immunofluorescence labelling. Briefly, NHOst grown on GBO particles were permeabilized with $0.5 \%$ Triton X-100 in PBS for 10 min, followed by blocking with 5\% skimmed milk in PBS for 30 min. Primary monoclonal antibodies to anti-human vinculin (Santa Cruz Biotechnology, Santa Cruz, CA; USA) was used, followed by Alexa Fluor 488 green fluorescence conjugated goat anti-mouse as secondary antibodies (Molecular Probes, Invitrogen, Eugene, OR, USA). Subsequently, the sample was incubated with Alexa Fluor 594 phalloidin red fluorescence conjugate (1:500, Molecular Probes), as a marker of the actin cytoskeleton. Before mounting for microscope observation, samples were briefly washed with $\mathrm{dH}_{2} \mathrm{O}$ and cell nuclei were stained with TOPRO 1:300 (Molecular Probes) for $5 \mathrm{~min}$. The glass coverslips were placed face down on glass slides and mounted with Prolong antifade (Molecular Probes).

Staining of samples was visualized using a Zeiss (Jena, Germany) LSM510 META confocal system, connected to an inverted Zeiss Axiovert 200 microscope equipped with a Plan Neofluar oil-immersion objective $(40 \times / 1.3 \mathrm{NA})$. Images were collected using an argon laser beam with excitation lines at $488 \mathrm{~nm}$ and a helium-neon source (543 $\mathrm{nm}$ and $665 \mathrm{~nm})$. 


\section{Mineralization assay}

Mineralization in osteoblast cultures was determined by Alizarin Red S staining. Cells were allowed to grow in differentiation medium for 28 days. Plates were fixed for $1 \mathrm{~h}$ in $4 \%$ paraformaldehyde in $0.1 \mathrm{M} \mathrm{PBS}, \mathrm{pH} 7.4$, washed three times with PBS ( $\mathrm{pH} 7.4$ ), then stained with $0.5 \%$ Alizarin Red $\mathrm{S}$ in $\mathrm{H}_{2} \mathrm{O}, \mathrm{pH} 4.0$, for $1 \mathrm{~h}$ at room temperature. After staining, the cultures were washed three times with $\mathrm{H}_{2} \mathrm{O}$ followed by $70 \%$ ethanol.

\section{Osteocalcin assay}

For the detection and quantification of osteocalcin in the supernatant of undifferentiated and differentiated NHOst, and differentiated NHOst with GBO, the Metra TM osteocalcin immunoassay (Quidel Corporation, San Diego, CA, USA) was used. The test is highly specific for intact osteocalcin quantitatively, and measures the osteocalcin levels in the supernatant. The test was performed according to the manufacturer's instructions and the supernatants were normalized according to the number of cells.

\section{Western Blot analysis}

The cells were, after four weeks of culture in OGM, resuspended in RIPA cold hypotonic lysis buffer (1x PBS, $1 \%$ Igepal, $0.5 \%$ sodium deoxycholate, $0.1 \%$ sodium dodecyl sulphate (SDS) and $10 \mu \mathrm{g} / \mathrm{ml}$ phenylmethylsulfonyl fluoride (PMSF), $10 \mu \mathrm{g} / \mathrm{ml}$ leupeptin and $10 \mu \mathrm{g} / \mathrm{ml}$ soybean trypsin inhibitor as inhibitors). The level of recovered protein was measured spectrometrically according to the instructions of the manufacturer using the Bio-Rad (Hercules, CA, USA) Protein Assay (detergent compatible).

Subsequently, $50 \mu \mathrm{g}$ of protein separated on SDSPAGE, was transferred to nitrocellulose sheets using a semidry blotting apparatus. Sheets were saturated for 60 min at $37^{\circ} \mathrm{C}$ in blocking buffer, then incubated overnight at $4{ }^{\circ} \mathrm{C}$ in blocking buffer (PBS supplemented with $5 \%$ normal goat serum (NGS) and $4 \%$ bovine serum albumin (BSA) containing primary antibodies such as: $\beta$-actin, collagen type I, OPN, BSP, BMP 2 and 7 (all from Santa Cruz Biotechnology, Santa Cruz, CA, USA). After four washes in PBS containing $0.1 \%$ Tween-20, they were incubated for $30 \mathrm{~min}$ at room temperature with peroxidaseconjugated secondary antibody diluted 1:5.000 in PBSTween-20, and washed as above. Bands were visualized by the ECL method; the different films were all exposed for the same period of time $(1 \mathrm{~min})$. The experiments were carried out in triplicate.

\section{Scanning electron microscopy (SEM) and energy dispersive $\mathrm{X}$-ray microanalysis (EDX)}

The samples were prefixed for $4 \mathrm{~h}$ at $4{ }^{\circ} \mathrm{C}$ in $2 \%$ glutaraldehyde in $0.05 \mathrm{M}$ phosphate buffer ( $\mathrm{pH} 7.4)$, postfixed in $1 \% \mathrm{OsO} 4$, dehydrated in increasing ethanol concentrations and then critical point-dried. They were then mounted on aluminium stubs and gold-coated in an Emitech K550 (EmitechLtd. Ashford, UK) sputter-coater before imaging by means of a SEM (LEO435Vp Cambridge, UK). The elemental content of the specimens was examined by means of EDX (Orciani et al., 2009).

\section{$\mathrm{Ca}^{2+}$ imaging and video microscopy experiments}

Video microscopy experiments were performed on confluent cells plated on the bottom of special 96 well plates (96 Well Special Optics Flat Clear Bottom Black Polystyrene TC-Treated Microplates; Corning, Corning, NY, USA) in the presence or not of GBO. For these experiments the cells were cultured in these multiwells as control cells, differentiated cells and differentiated cells grown on GBO. Changes in free cytosolic $\mathrm{Ca}^{2+}$ were measured in response to $20 \mathrm{nM}$ human Parathyroid Hormone (PTH) and $1 \mathrm{nM}$ human Calcitonin (CT) in the presence and in the absence of (s)-(-)-Propranolol hydrochloride $(1 \mu \mathrm{g} / \mathrm{ml})$, a $\beta$-adrenoceptor antagonist. Temporal plots were calculated as the mean value of the fluorescence signal $(f)$ in a selected representative cellular area after the subtraction of background fluorescence $\left(f_{0}\right)$.

\section{Statistical analysis}

Statistical analysis was performed using the software package Sigma Stat 3.5 (SPSS Inc., Ekrath, Germany). To test the hypothesis of no differences between the several treatment groups, One Way ANOVA was used, while the Holm Sidak test was used to isolate all the pair-wise differences among the experimental groups. Moreover, the differences in the densitometric analysis and the MTT assay were evaluated using a non-parametric test (MannWhitney Rank Sum Test). A $P$-value of $<0.05$ was considered statistically significant.

\section{Results}

In the present study, normal human primary osteoblasts from Clonetics (Lonza) tested by the company for alkaline phosphatase (ALP), type I collagen, osteocalcin, CD44 and von Kossa mineralized nodules were used.

In vitro cell culture provides an ideal tool to investigate specific different biomaterial scaffolds, and the current study assessed the cellular response to GBO particles. A plating efficiency assay verified that after $12 \mathrm{~h}$ the cells were adherent to the scaffold previously incubated overnight with OBM medium. During the first contact between cells and the biomaterials no significant difficulty in the adhesiveness process was observed, confirming the biocompatibility of the three-dimensional biomaterials examined. For this purpose, the focal adhesions between the NHOst cells and GBO particles were evaluated using confocal laser microscopy. The immunohistochemistry results showed that a specific positive response to vinculin was present on the biomaterial surface, indicating that an intimate contact between cells and GBO particles was established. The actin filaments, stained with rodhaminephalloidin, showed the spatial organization of the cells in intimate contact with the biomaterial particles (Fig. 1). Subsequently, the proliferation rate and the viability were studied by performing a trypan blue exclusion test at different times, and by MTT assay. The results showed an analogous cell growth at early times in induced cells with biomaterials (Fig. 2a and b). Light microscopy of the cell cultures showed that most of the NHOst exhibited a 

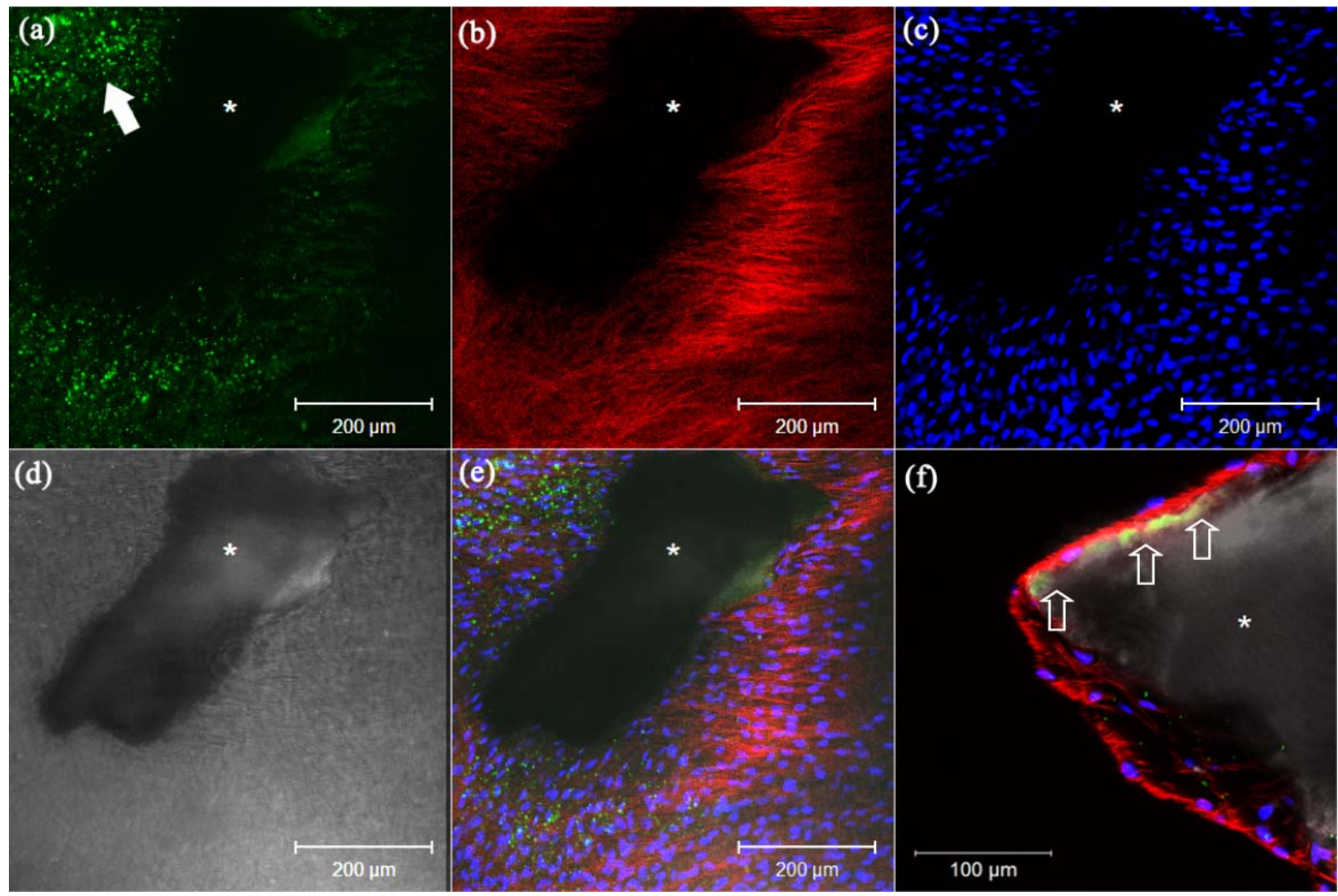

Fig. 1. Representative images of NHOst seeded on GBO expressing vinculin and actin. Section a: A punctate vinculin labelling was clearly observed in cells adhering to the substrate (green fluorescence). Section b: Cytoskeleton actin filament arrangement of the human osteoblasts attached to bioparticles was detectable by rhodamine-phalloidin staining (red fluorescence). Section c: The nuclei were visualized by TOPRO (Blue signal). Section d: RGB white and black detection of GBO granules. The GBO was present as gray paint. Sections e and f: Merged images indicated the triple staining of NHOst seeded on the biomaterial. Asterisk: GBO, arrows: vinculin immunoprecipitate.
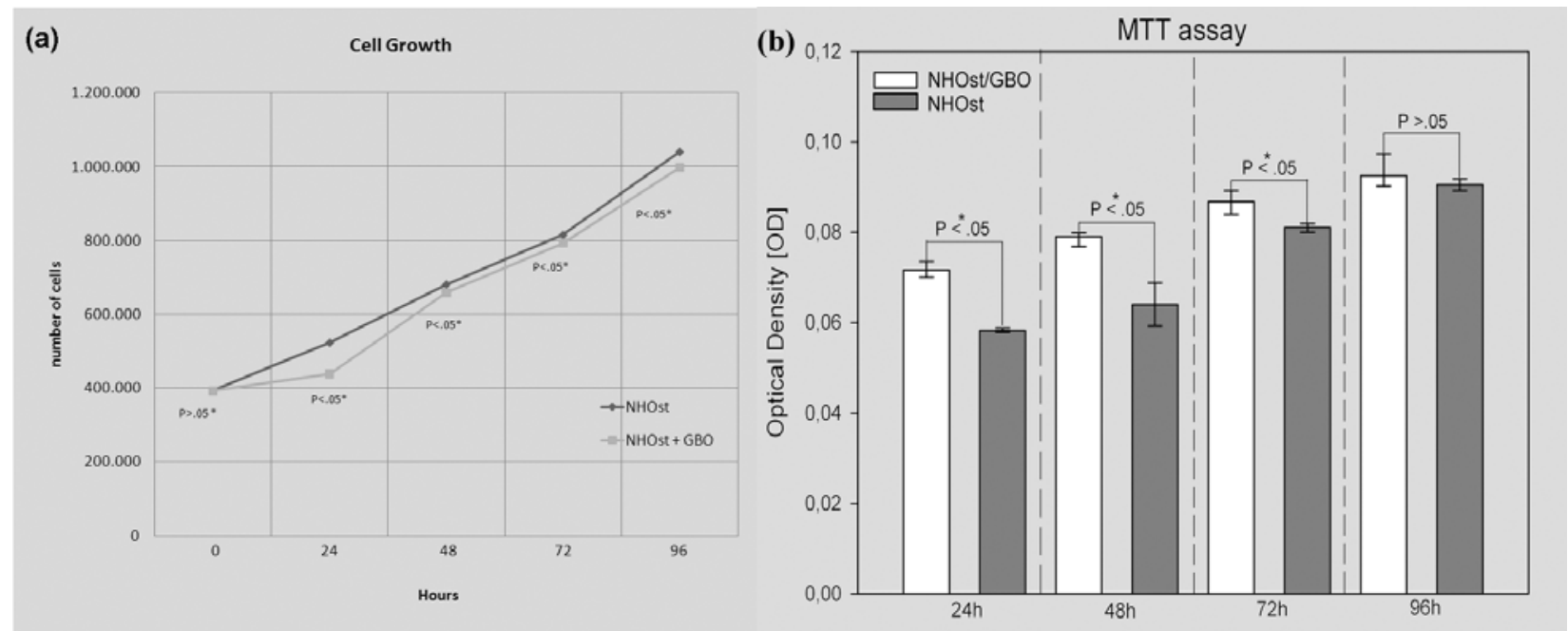

Fig. 2. Representative data indicating the proliferation rate and viability performed by trypan blue exclusion test. An analogous cell growth was evident on induced NHOst cells either seeded or not on biomaterial until to $96 \mathrm{~h}$ of culture ( section a). The $Y$ axis showed cell numbers (mean \pm S.D. of three separate experiments). (*) statistical significance. In section $\mathbf{b}$ the results from the MTT assay were reported. The data obtained pointed out the same trend observed by the trypan blue test. The fluorimeter reading made at a $650 \mathrm{~nm}$ wavelength and represented as median $( \pm$ SD) of four separate experiments per condition were compared using Mann-Whitney Rank Sum Test. The differences appeared to be significantly different $\left(^{*}\right)$ after 24 h, 48 h and $72 \mathrm{~h}$, while they were not significantly different after $96 \mathrm{~h}$. 


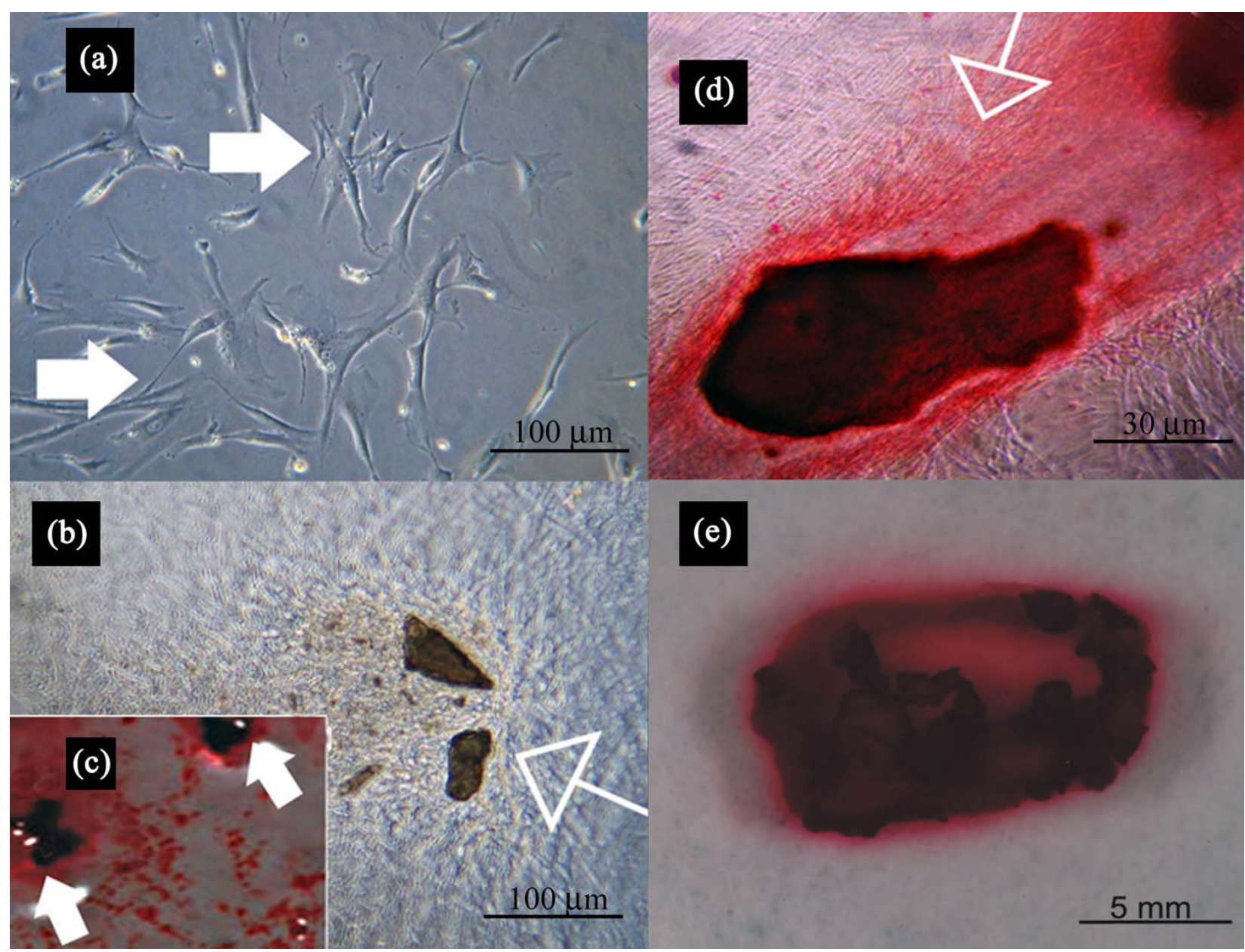

Fig. 3. (a) Photomicrograph of a primary culture of human osteoblasts cells line expanded ex vivo showed a morphological homogeneous fibroblast-like appearance with a stellate shape and elongated cytoplasmic processes. (b) Confluent living induced NHOst cells grown on tridimensional GBO. Cellular margin were indiscernible for the intimate contact between neighbouring cells. (c) The induced cells in presence of GBO showed a characteristic arrangement, and, in fact, several areas of mineralization shown by Alizarin Red staining were present. The empty arrows showed the bone nodule containing the biomaterials; little nodules, positive to alizarin red without the biomaterial, were present. (d) High magnification revealed adhesion and continuous contact of induced NHOst cells to substrate, and, in fact, confluent cells were observed on the biomaterial surface. The intense alizarin Red positivity showed clearly a massive osteogenic differentiation. (e) Macroscopic images at four weeks of osteogenic induction. The cellular monolayer was completely detached from the bottom well; the induced cells captured some biomaterial particles forming an isolated bone nodule (arrow) as demonstrated by a high level of mineralization by alizarin red.

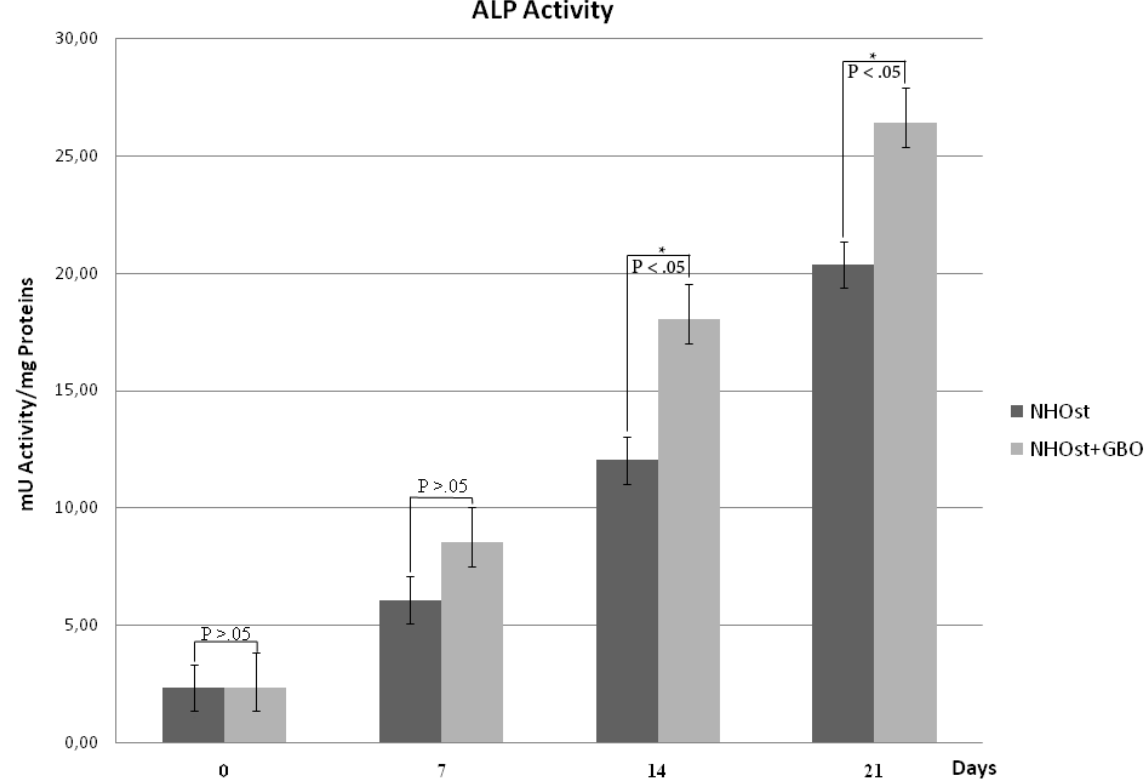

Fig. 4. ALP activity assay. ALP activity was evaluated in cells treated with osteoinductive medium in presence or in absence of GBO at different time of induction (mean \pm standard deviation of three separate experiments). (*) statistical significance. 

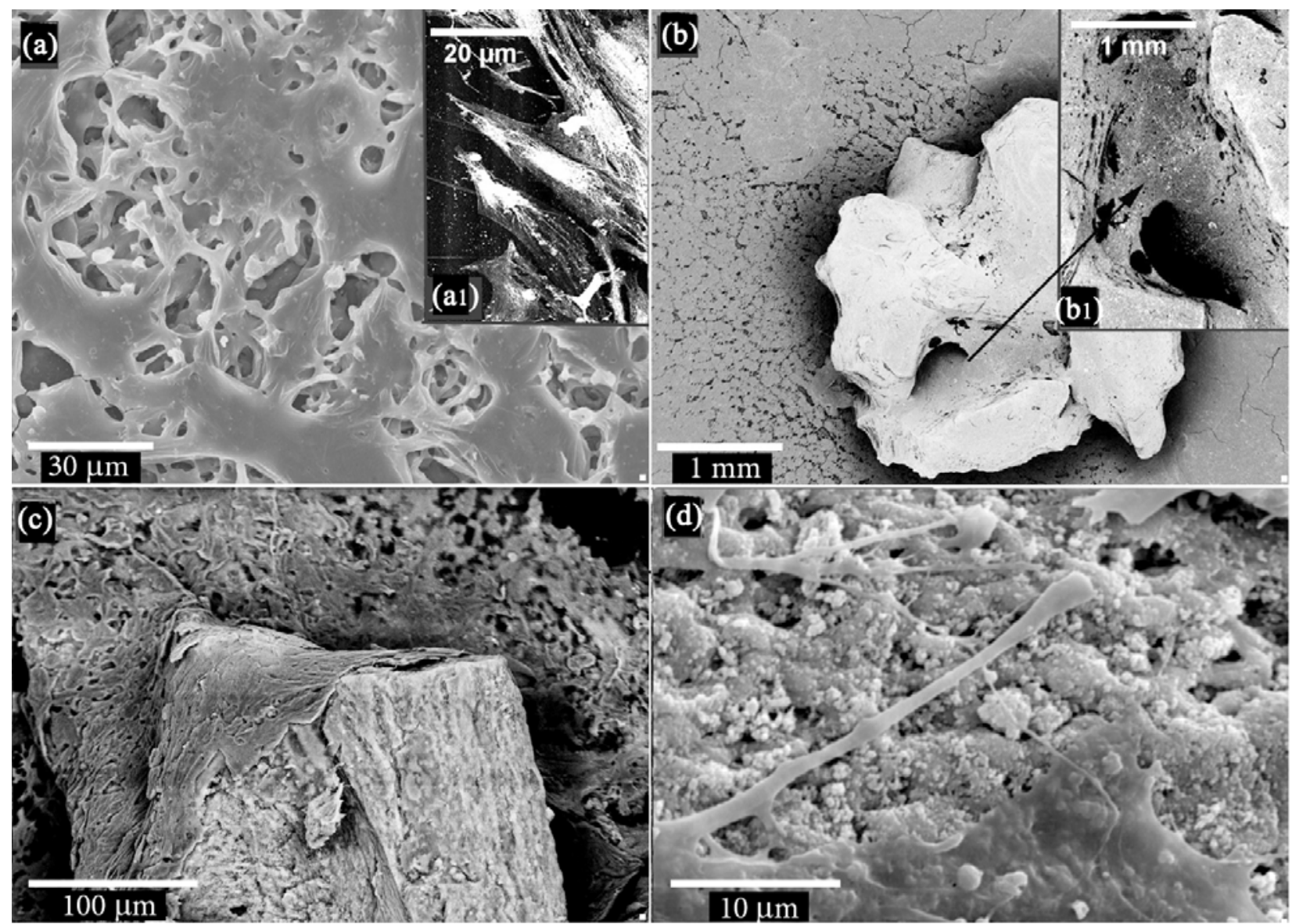

Fig. 5. Photomicrograph of primary cultures of NHOst cells after four week of culture in the presences of osteoinductive medium. Section a displayed NHOst cells with cuboidal-like shape, contact zones between confluent cells were visible. The inset of Figure al showed NHOst cells consisting of adherent cells showing a morphological homogeneous fibroblast-like appearance with a stellate shape and long cytoplasmic processes. Section b exhibited cellular proliferation and colonization of the biomaterial. The cells made a contact and covered the biomaterials geometry surface (Fig. 5b1, inset). At higher magnification, sections $\mathbf{c}$ and $\mathbf{d}$ demonstrate marked interactions between the cells and the substrate obtained through extending cytoplasmic elongation and filopodia. The distal end of the filopodia and cytoplasmic processes were strongly attached to the GBO substrate.

characteristic spindle-like shape (Fig. 3a). The investigation of NHOst, induced to osteogenesis and seeded on three-dimensional scaffolds, gave an idea about their behaviour in the presence of bovine bone biomaterials. In particular, the cells adhered directly to the substrate, grew without inhibition (Fig. 3b), and formed cellular structures such as bone nodules and calcified extracellular matrix, strongly stained by Alizarin Red S (Fig. 3c). Fig. 3d shows, at high magnification, that the cells grown on the particle form a confluent cellular multilayer; these cells, adherent to the biomaterial particles, were strongly positive to Alizarin Red staining. At a later stage of osteogenesis stimulation, the adherent cells completely lost the adhesiveness to the bottom of the flask, and produced an isolated bone nodule entrapping the biomaterial particles. Newly formed tissue resulted, that was clearly stained by Alizarin Red.

Alkaline phosphatase activity, an intermediate marker for osteoblast differentiation, was analysed in NHOst cells seeded or not seeded on biomaterials, and cultured in presence of the inductive medium. The cells showed an increased alkaline phosphatase activity at 7, 14, 21 days, significantly evident in samples with GBO after 14 and 21 days (Fig. 4).

SEM observations helped to clarify the behaviour of cells in contact with the biomaterial. No signs of biomaterial degradation were observed at the conclusion of the treatment. Photomicrographs of primary cultures of NHOst cells after 4 weeks of culture, in the presence of osteoinductive medium, showed a specific cell morphology: in particular, contact zones between flattened confluent cells with polygonal morphology were detectable (Fig. 5a). The inset of Fig. 5a shows adherent NHOst cells showing a morphologically homogeneous fibroblast-like appearance with a stellate shape and long cytoplasmic processes. Fig. 5 b displays extensive cellular proliferation and colonization on the bovine-derived bone substitute and close contacts between the cells and the substrate (Fig. $5 \mathrm{~b}$, insert). At higher magnification, Fig. $5 \mathrm{c}$ shows marked interactions between the cells covering the GBO. This contact was established through extending cytoplasmic processes and filopodia, which enabled the anchorage of 

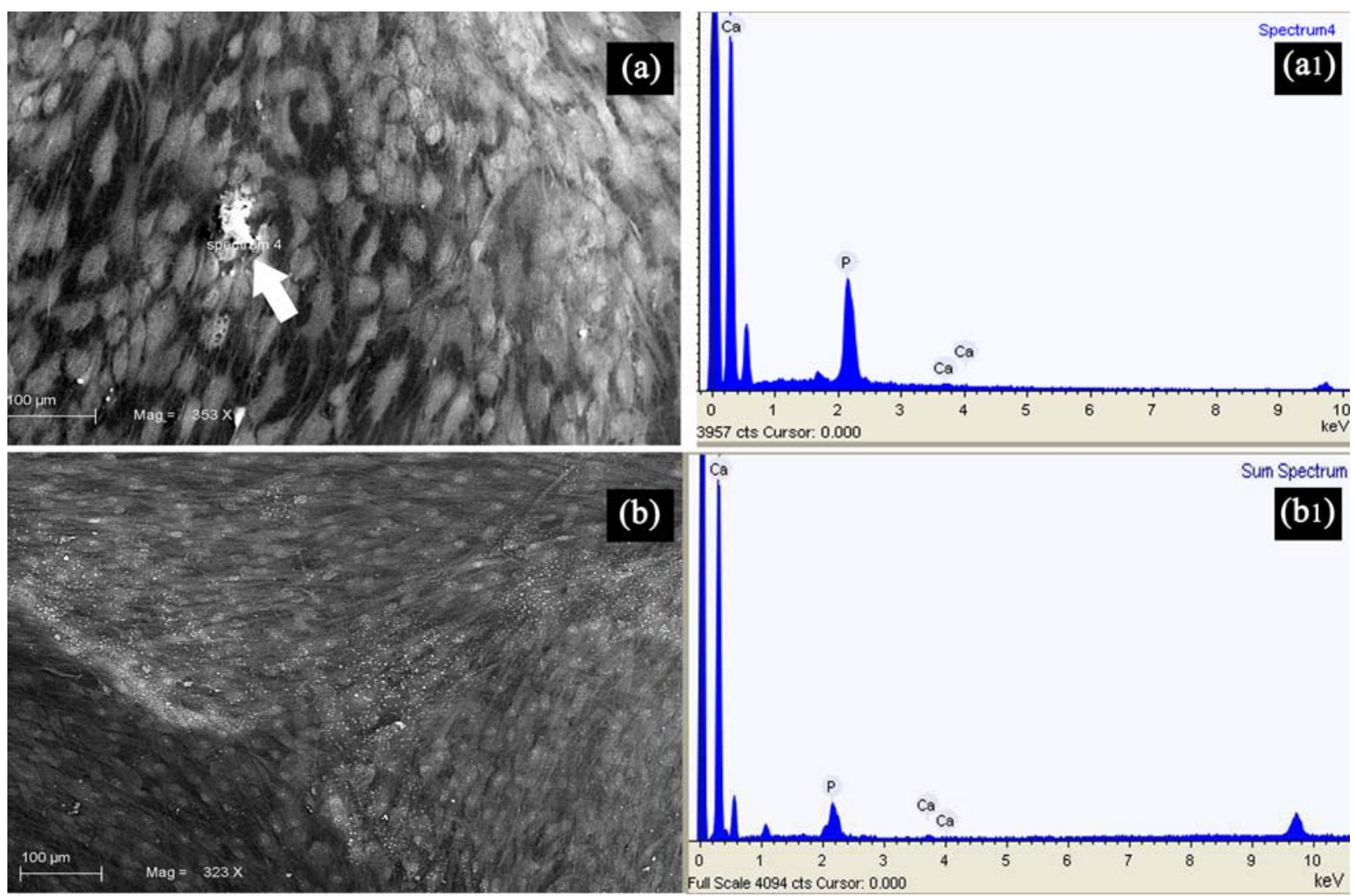

Fig. 6. Photomicrograph a, and b showed cell culture of test and control groups respectively under SEM ( a1 and b1) reporting the results of the energy dispersive-x ray microanalysis. Mineralized deposits containing calcium and phosphorus were frequently observed in the test group (a1) by characteristic EDX patterns (white arrow).

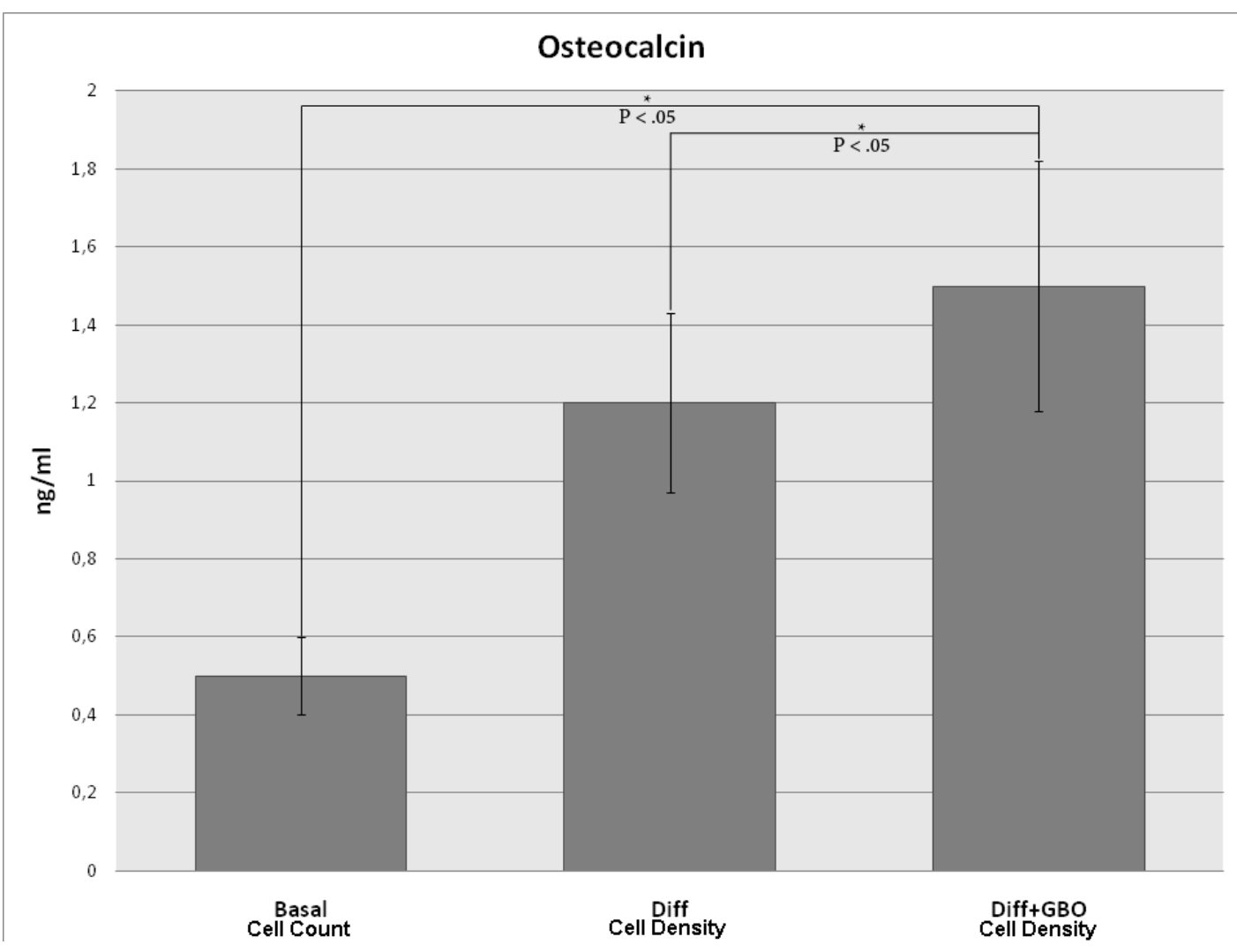

Fig. 7. This micrograph shows the osteocalcin level measured in supernatant after 1 week of culture in control cells, osteogenic induced NHOst, without and with GBO particles. Data were from one of four replicate experiments, all yielding nearly identical results. The reaction product was measured as optical density (OD) at $405 \mathrm{~nm}$. (*) statistical significance. 
(a)

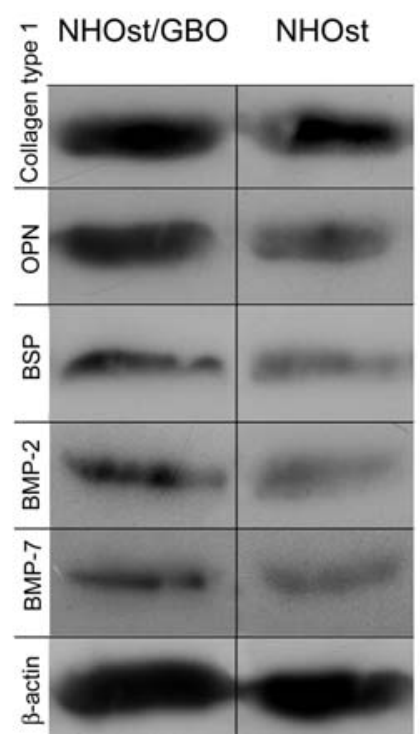

(b)
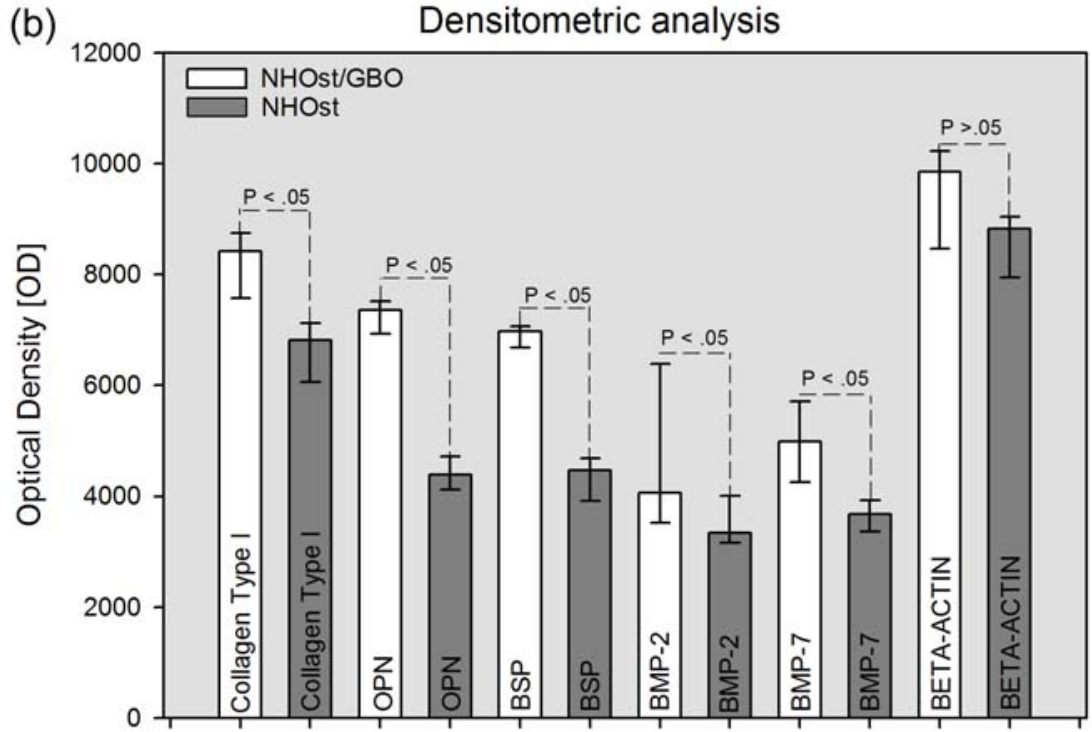

Fig. 8. Immunoblotting experiments (section a) and densitometric analysis (section b) of OPN, BSP, BMP-2, BMP-7 and Type 1 collagen expression evaluated as described in Materials and Methods. Western blot study and densitometric analysis confirmed that the abovementioned molecules were expressed at higher levels in differentiating cells with GBO. The median ( \pm S.D) of three separate experiments, compared using the Mann-Whitney Rank Sum Test, appeared to be significantly different from $\beta$-actin that was used as housekeeping protein.
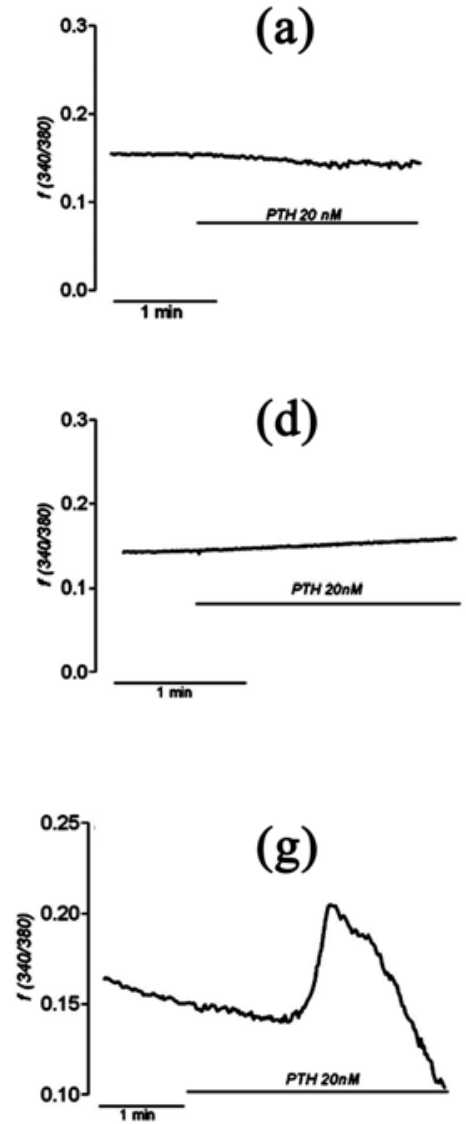

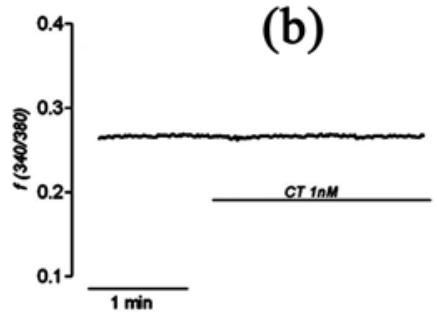

(e)

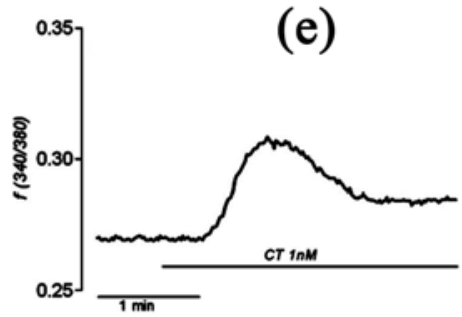

(h)

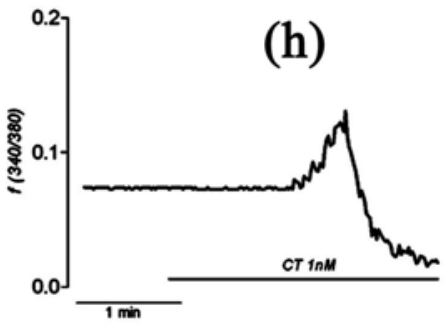

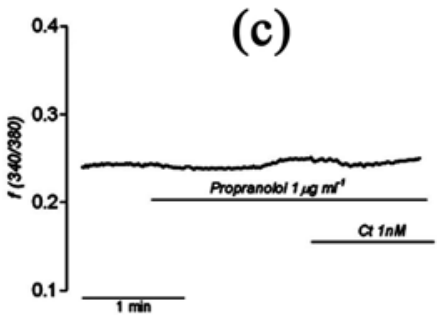
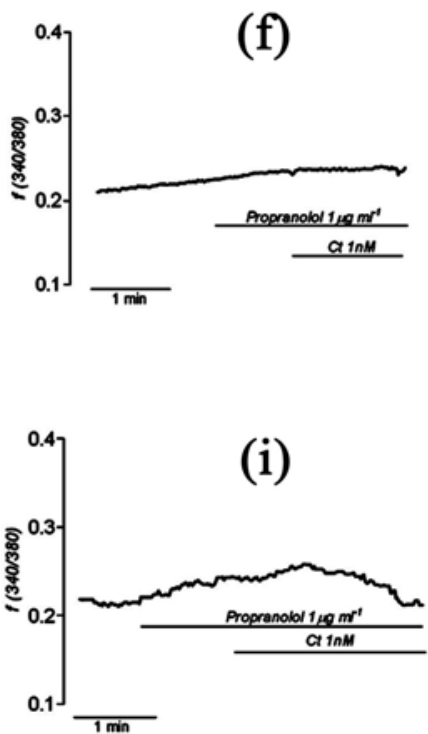

Fig. 9. Effects of PTH, CT and Propanolol $+\mathrm{CT}$ on $\left[\mathrm{Ca}^{2+}\right]_{\mathrm{i}}$ in NHOst. In panels a, $\mathbf{d}$ and $\mathbf{g}$ the responses to $20 \mathrm{nM}$ PTH are shown in (a) undifferentiated cells (d), differentiated cells, (g) differentiated cells + GBO. In panel b, e and $\mathbf{h}$ the responses to $1 \mathrm{nM} \mathrm{CT}$ are shown in (b) undifferentiated cells, (e), differentiated cells, and (h) and differentiated cells + GBO. In panels $\mathbf{c}, \mathbf{f}$ and $\mathbf{i}$ the responses at preincubation for 2 minutes with $1 \mathrm{mg} / \mathrm{ml}$ propanolol followed by oreicubation with propanolol plus $1 \mathrm{nM} \mathrm{CT}$ are shown in (c) undifferentiated cells, (f) differentiated cells and (i) differentiated cells + GBO. These graphs are representative of several measurements performed on at least 15 cells in each condition. 
the cells; in fact, the distal end of the filopodia and cytoplasmic processes were directly associated with the constituent part of the biomaterials (Fig. 5d).

The results of the energy-dispersive X-ray microanalysis showed the presence of mineralized deposits containing calcium and phosphorus (Fig. 6a).

The osteocalcin level, estimated using the immunoassay test, increased in the supernatant of differentiated NHOst incubated with GBO in comparison with differentiated and basal NHOst (Fig. 7).

Western blot analysis showed in samples seeded with the biomaterial a modulation of all bone tissue-specific proteins examined. In particular BSP, OPN, and collagen type I were detected, demonstrating an evident maturation of bone cells (Fig. 8a). Densitometric analysis confirmed the results observed by Western blot investigation (Fig. $8 b)$.

To verify the functional capacity of these cells as osteoblastic phenotype, some experiments of $\left[\mathrm{Ca}^{2+}\right]$ analysis utilizing fluorescence conventional video microscopy, in the presence of $20 \mathrm{nM} \mathrm{PTH}$, or $1 \mathrm{nM} \mathrm{CT}$ with or without $1 \mu \mathrm{g} / \mathrm{ml}$ propanolol, were performed. In all situations, the undifferentiated cells cultured in presence of GBO did not show any variation of $\left[\mathrm{Ca}^{2+}\right]_{\mathrm{i}}$ (Fig. 9a, b and $\mathrm{c}$ ), while the differentiated cells without biomaterial responded only to $1 \mathrm{nM} \mathrm{CT}$ (Fig. 9d, e and f). The differentiated cells cultured in the presence of biomaterials were responsive both to PTH and CT (Fig. 9g and h). The preincubation with proponalol blocked the response to CT (Fig. 9i). These results seemed to confirm the functional osteogenic characteristics of the differentiated cells.

\section{Discussion}

A variety of bone grafts has been used to repair bone defects caused by diseases or trauma, bone loss, bone infections, or bone tumours. Bone growth and integration with the biomaterial used in medical devices is dependent on the recruitment, attachment, and differentiation of the cellular components that are essential for bone formation and development (Petite et al., 2000; Rose and Oreffo, 2002). To optimize and modulate bone formation, it is critical to understand the expression patterns of the key - bone specific growth factors involved in the processes of maturation and mineralization. In this study, the expression of selected growth factors and proteins related to the osteogenic differentiation in cells cultured in presence of 3-D biomaterials were delineated; in fact, cell culture represented a perfect instrument for investigating new materials for tissue regeneration before their use in clinical applications.

Multiple in vitro and in vivo studies confirmed that bone-specific growth factors exerted autocrine and paracrine effects on the proliferation, differentiation, and maturation of osteoprogenitor cells. In particular, many studies linked PDGF with bone cell growth and differentiation (Lalani et al., 2003), and in addition, BMP2 and TGF- $\beta$ influenced bone healing after tooth extraction (Celeste et al., 1990). Members of the TGF- $\beta$ superfamily, the BMPs, have been demonstrated to have an important role in articular cartilage, osteoblasts, and osteoprogenitor cells, and, surprisingly, also in osteoclasts (Anderson et al., 2000).

In vivo bone formation includes chemotaxis and proliferation of osteoprogenitor cells, and differentiation into osteoblasts that secrete extracellular matrix protein, such as collagen type I (Alonso et al., 2008). Besides distinct "master genes" which control the progression of osteogenic differentiation, it is believed that this process is controlled also by a cascade of molecular events involving a combination of genetic programming and gene regulation by various molecules such as alkaline phosphatase, osteopontin, bone sialoprotein, and osteonectin (Wang, 2003). The tissue engineering approach for bone regeneration and repair is a new challenge in oral and maxillofacial surgery (Bianco and Robey, 2001; Yamada et al., 2004; Lauer and Schimming, 2001; Zietek et al., 2008). Bone regeneration could be supported by a scaffold that has to be biocompatible, biodegradable, and able to support cell growth and differentiation (Huang et al., 2007).

The present data showed cellular proliferation of the NHOst cells and subsequent colonization of the biomaterial, and, in fact the uppermost surface was covered with adherent cells, forming a network between the granules. The cells cultured in inductive medium secreted extracellular matrix, and the presence of mineralised matrix was confirmed after four weeks by Alizarin Red S, which is able to stain extracellular matrix containing calcium deposits, and by energy dispersive X-ray microanalysis. These data were in agreement with the alkaline phosphatase increase and the cell morphology changes as demonstrated for human MSCs during osteogenic differentiation (Born et al., 2009). In fact, ultrastructural analysis showed induced cells with a more spherical shape with short elongations, and the focal contacts between neighbouring cells were evident indicating a pseudoepithelial arrangement of osteoblasts during osteoid deposition. NHOst adhered to the biomaterial and organized cellular bridges across the particles, and a marked mineralised extracellular matrix was evident around the biomaterial particles. At the end of the inductive process the monolayer lost the adhesion to the bottom of the flask, and formed a single bone nodule intensively stained by Alizarin Red. The analysis of cytoskeletal proteins represents a way to study new and already existing biomaterials (Born et al., 2009). Fluorescently tagged vinculin has previously been used to demonstrate that the surface features of biomaterials made of either titanium or stainless steel are critical for number, size and dynamics of focal adhesions (Diener et al., 2005), and that the focal adhesion area increases in osteogenic cells (Born et al., 2009). In NHOst cells numerous anchoring junctions bind cells to the substrate, indicating that the above mentioned biomaterials offered an adequate support for tissue reconstruction due to their biological characteristics and their ability to support growth and differentiation. Also, the biochemical analysis showed that during osteogenic induction the NHOst cells still produced osteoinductive factors, but higher levels were 
present in NHOst cultured in the presence of GBO. These data were supported also by the increase of osteocalcin levels in NHOst seeded with the GBO. Osteocalcin is the most abundant noncollagenous protein in the mineralized bone matrix and its increase showed that the biomaterial could be an inductor of osteogenesis in vitro. As already demonstrated in mesenchymal stem cells obtained from the periodontal ligament (Trubiani et al., 2007; Trubiani et al., 2008), GBO did not interfere with the growth, migration and differentiation of the cells but, on the contrary, could be a stimulus for a more significant osteogenic differentiation, alkaline phosphatase increase, and mineralized matrix production (Trubiani et al., 2007; Trubiani et al., 2008).

Bone is the major store for calcium and it fulfils essential roles in the maintenance of $\left[\mathrm{Ca}^{2+}\right]$ within its homeostatic range $(1.1-1.3 \mathrm{mM})$ (Dvorak and Riccardi, 2004). In response to hyper- or hypocalcaemia this ion is rapidly transported into or out of bone by the metabolic actions of osteoblasts and osteoclasts. Exchanges of calcium ions between plasma and bone tissue depend on both concentration gradients (rapid mechanism although negligible of minimal entity) and effects of specific hormones of which the regulation is slower but more sustained, and controlled by feedback mechanisms. These hormones are PTH and CT. PTH is secreted in response to a decrease in calcium plasma concentrations and it promotes the release of this ion from the bone. The osteoblasts respond to $\mathrm{PTH}$ with a rapid increase in intracellular calcium concentration $\left(\left[\mathrm{Ca}^{2+}\right]_{\mathrm{i}}\right)$ (Ryder and Duncan, 2001), that is released from intracellular stores and subsequently will be pumped out of the cell. CT has the opposite effect on this tissue, promoting the uptake of calcium from the extracellular environment, which always leads to an increase in $\left(\left[\mathrm{Ca}^{2+}\right]_{\mathrm{i}}\right)$. These hormones have specific receptors in the plasma membranes of bone cells (Lerner and Lundberg, 2002). The binding of CT to its receptors (Lerner and Person, 2008) is inhibited by blockers of $\beta$-adrenergic receptors, such as propanolol (Maurizi et al., 1988; Togari et al., 1997). Several papers in the literature have reported that primary cultures of human osteoblast-like cells expressed a CT receptor-like receptor (CLR) (Villa et al., 2006) and as other osteoblastlike cells (UMR-106) possessed CT- and PTH receptors (Yamaguchi et al., 1987).

The primary human osteoblasts (NHOst) that we have tested showed a clear and significant response to the specific hormones, resulting in an increase in the $\left(\left[\mathrm{Ca}^{2+}\right]_{\mathrm{i}}\right)$ only when they were differentiated. These results confirm that the responses were specific and mediated by the presence of specific receptors for these hormones on the cell surface. In fact, the undifferentiated cells that did not still express these receptors showed no response to stimuli. The addition of propanolol before calcitonin, which blocked the transduction pathway of this hormone, inhibited the response to $\mathrm{CT}$, further confirming the presence of specific receptors for this hormone. CT has been widely studied as a therapy for postmenopausal osteoporosis for its inhibitory effects on bone resorption (Austin and H 1981); it not only suppresses the activity of mature isolated osteoclasts but also inhibits osteoclast development in bone marrow cultures (Cornish et al., 2001).

Moreover, recent in vivo human reports have been demonstrated that after 20 months the GBO particles at the bone-biomaterial interface show a relatively high calcium content (Traini et al., 2008). In vivo the calcium content around the biomaterial particles could stimulate an increase of calcitonin that acting on osteoclasts reduced the resorption; in fact, after 9 years, the tissue pattern of retrieved bone specimens appeared composed of many residual GBO particles in close contact with newly formed bone, with less than $3 \%$ of biomaterial resorption over five years (Traini et al., 2007).

In conclusion, the present results regarding the adhesion, proliferation, differentiation and response to calciotropic hormone of the cells with an osteoblastic phenotype seeded on 3-D biomaterial particles suggested that the use of a biomaterial may represent a valuable alternative to autologous bone transplantation for the reconstruction of the osteogenic defect. In particular, they show that GBO harbours a great potential for hard tissue engineering purposes, and confirm the results obtained in clinical practice (Orsini et al., 2005; Orsini et al., 2007). However, additional clinical and in vitro studies are necessary to verify the functional response of the mesenchymal stem cells in presence of 3-D biomaterials.

\section{Acknowledgments}

This work has been funded by a grant from the Osteology Foundation, Lucerne, Switzerland and the Carichieti Foundation, Chieti, Italy.

\section{References}

Acil Y, Sringer IN, Broek V, Terheyden H, Jepsen S (2002) Effects of bone morphogenetic protein-7 stimulation on osteoblasts cultured on different biomaterials. J Cell Biochem 86: 90-98.

Al-Saffar N, Revell PA (2000) Frustrated wound healing: the immunopathogenesis of bone resorption. In: Bone Engineering (Davies JE, ed), EM Squared Inc, Toronto, Ontario, Canada chapter 13, pp.152-160.

Alonso M, Claros S, Becerra J, Andrades JA (2008) The effect of type I collagen on osteochondrogenic differentiation in adipose-derived stromal cells in vivo. Cytotherapy 10: 597-610.

Anderson HC, Hodges PT, Aguilera XM, Missana L, Moylan PE (2000) Bone morphogenetic protein (BMP) localization in developing human and rat growth plate, metaphysic, epiphysis, and articular cartilage. J Histochem Cytochem 48: 1493-1502.

Araújo MG, Lindhe J. (2009) Ridge preservation with the use of Bio-Oss collagen: A 6-month study in the dog. Clin Oral Implants Res. 20: 433-440.

Austin LA, Heath 3rd H (1981) Calcitonin: physiology and pathophysiology. N Engl J Med 304: 269-278. 
Bianco P, Robey PG (2001) Stem cells in tissue engineering. Nature 414: 118-121.

Born AK, Rottmar M, Lischer S, Pleskova M, Bruinink A, Maniura-Weber K (2009) Correlating cell architecture with osteogenesis: first steps towards live single cell monitoring. Eur Cell Mater 18: 49-62.

Celeste AJ, Iannazzi JA, Taylor RC, Hewick RM, Rosen V, Wang EA, Wozney JM (1990) Identification of transforming growth factor beta family members present in bone-inductive protein purified from bovine bone. Proc Natl Acad Sci U S A 87: 9843-9847.

Cornish J, Callon KE, Bava U, Kamona SA, Cooper GJ, Reid IR (2001) Effects of calcitonin, amylin, and calcitonin gene-related peptide on osteoclast development. Bone 29: 162-168.

Cowan CM, Soo C, Ting K, Wu B (2005) Evolving concepts in bone tissue engineering. Curr Top Dev Biol 66: $239-85$

Diener A, Nebe B, Lüthen F, Becker P, Beck U, Neumann HG, Rychly J (2005) Control of focal adhesion dynamics by material surface characteristics. Biomaterials 26: 383-392.

Dvorak M, Riccardi D (2004) $\mathrm{Ca}^{2+}$ as an extracellular signal in bone. Cell Calcium 35: 249-255.

Griffith LG, Naughton G (2002) Tissue engineeringcurrent challenges and expanding opportunities. Science 295: 1009-1014.

Hench LL, Polak JM (2002) Third-generation biomedical materials. Science 295: 1014-1017.

Hubbell JA (1999) Bioactive biomaterials. Curr Opin Biotechnol. 10: 123-129.

Huang Z, Nelson ER, Smith RL, Goodman SB (2007) The sequential expression profiles of growth factors from osteoprogenitors to osteoblasts in vitro. Tissue Eng 13: 2311-2320.

Jensen SS, Broggini N, Hjørting-Hansen E, Schenk R, Buser D (2006) Bone healing and graft resorption of autograft, anorganic bovine bone and beta-tricalcium phosphate. A histologic and histomorphometric study in the mandibles of minipigs. Clin Oral Implants Res 17: 237243.

Lalani Z, Wong M, Brey EM, Mikos AG, Duke PJ (2003) Spatial and temporal localization of transforming growth factor-beta1, bone morphogenetic protein-2, and platelet-derived growth factor-A in healing tooth extraction sockets in a rabbit model. J Oral Maxillofac Surg 61: 10611072.

Lauer G, Schimming R (2001) Tissue-engineered mucosa graft for reconstruction of the intraoral lining after freeing of the tongue: a clinical and immunohistologic study. J Oral Maxillofac Surg 59: 169-175.

Lerner UH, Lundberg P (2002) Kinins and neuroosteogenic factors. In: Principles of Bone Biology, 2nd ed (Bilezikian JP, Raisz LG, Rodan GA, eds.) Academic Press, San Diego. pp. 773-799.

Lerner UH, Persson E (2008) Osteotropic effects by the neuropeptides calcitonin gene-related peptide, substance $\mathrm{P}$ and vasoactive intestinal peptide. J Musculoskelet Neuronal Interact 8: 154-165.
Lohmann CH, Tandy EM, Sylvia VL, Hell-Vocke AK, Cochran DL, Dean DD, Boyan BD, Schwartz Z (2002) Response of normal female human osteoblasts (NHOst) to 17-estradiol is modulated by implant surface morphology. J Biomed Mater Res. 62:204-213.

Maurizi M, Donti E, Fanò G, Paludetti G, Ottaviani F, Fulle S, Venti-Donti G (1988) Study on normal and otosclerotic bone cell cultures: an advance in understanding the pathogenesis of otosclerosis. Am J Otolaryngol 9: 6878.

Orciani M, Trubiani O, Vignini A, Mattioli-Belmonte M, Di Primio R, Salvolini E (2009) Nitric oxide production during the osteogenic differentiation of human periodontal ligament mesenchymal stem cells. Acta Histochem 111: $15-24$.

Orsini G, Traini T, Scarano A, Perrotti V, Piccirilli M, Piattelli A (2005) Maxillary sinus augmentation with BioOss 1 particles: A light, scanning and transmission electron microscopy study in man. J Biomed Mater Res B Appl Biomater 74: 448-457.

Orsini G, Scarano A, Degidi M, Caputi S, Iezzi G, Piattelli A (2007) Histological and ultrastructural evaluation of bone around Bio-Oss1 particles in sinus augmentation. Oral Dis 13: 586-593.

Petite H, Viateau W, Meunier A, de Pollac C, Bourguignon M, Oudina K, Sedel L, Giullemin G (2000) Tissue engineered bone regeneration. Nat Biotechnol 18: 959-963.

Piattelli M, Favero GA, Scarano A, Orsini G, Piattelli A (1999) Bone reactions to anorganic bovine bone (BioOss) used in sinus augmentation procedures: a histologic long-term report of 20 cases in humans. Int J Oral Maxillofac Implants 14: 835-840.

Rose FR, Oreffo RO (2002) Bone tissue engineering: hope vs hype. Biochem Biophys Res Commun 292: 1-7.

Ryder KD, Duncan RL. (2001) Parathyroid hormone enhances fluid shear-induced $\left[\mathrm{Ca}^{2+}\right]_{i}$ signaling in osteoblastic cells through activation of mechanosensitive and voltage-sensitive $\mathrm{Ca}^{2+}$ channels. J Bone Miner Res 16: $240-248$.

Sartori S, Silvestri M, Forni F, Icaro Cornaglia A, Tesei P, Cattaneo V (2003) Ten-year follow-up in a maxillary sinus augmentation using anorganic bovine bone (BioOss). A case report with histomorphometric evaluation. Clin Oral Implants Res 14: 369-372.

Schmitt SC, Wiedmann-Al-Ahmad M, Kuschnierz J, Al-Ahmad A, Huebner U, Schmelzeisen R, Gutwald R (2008) Comparative in vitro study of the proliferation and growth ovine osteoblast-like cells on various alloplastic biomaterials manufactured for augmentation and reconstruction of tissue or bone defects. J Mater Sci Mater Med 19: 1441-1450.

Sodek J, Cheifetz, S (2000) Molecular Regulation of Osteogenesis. In: Bone Engineering (Davies JE, ed), EM Squared Inc, Toronto, Ontario, Canada, pp. 31-43.

Togari A, Arai M, Mizutani S, Mizutani S, Koshihara Y, Nagatsu T (1997) Expression of mRNAs for neuropeptide receptors and b-adrenergic receptors in human osteoblasts and human osteogenic sarcoma cells. Neurosci Lett 233:125-128. 
Traini T, Valentini P, Iezzi G, Piattelli A (2007) A histologic and histomorphometric evaluation of anorganic bovine bone retrieved 9 years after a sinus augmentation procedure. J Periodontol 78: 955-961.

Traini T, Degidi M, Sammons R, Stanley P, Piattelli A. (2008) Histologic and elemental microanalytical study of anorganic bovine bone substitution following sinus floor augmentation in humans. J Periodontol. 79:1232-40.

Trubiani O, Scarano A, Orsini G, Di Iorio D, D’Arcangelo C, Piccirilli M, Sigismondo M, Caputi S (2007) The performance of human periodontal ligament mesenchymal stem cells on xenogenic biomaterials. Int J Immunopathol Pharmacol 20: 87-91.

Trubiani O, Orsini G, Zini N, Di Iorio D, Piccirilli M, Piattelli A, Caputi S (2008) Regenerative potential of human periodontal ligament derived stem cells on threedimensional biomaterials: a morphological report. J Biomed Mater Res A 87: 986-993.

Turhani D, Weißenböck M, Watzinger E, Yerit K, Cvikl B, Ewers R, Thurnher D (2005) In vitro study of adherent mandibular osteoblast-like cells on carrier materials. Int J Oral Maxillofac Surg 34: 543-550.

Villa I, Mrak E, Rubinacci A, Ravasi F, Guidobono F (2006) CGRP inhibits osteoprotegerin production in human osteoblast-like cells via cAMP/PKA-dependent pathway. Am J Physiol Cell Physiol. 291: 529-537.

Wang M (2003) Developing bioactive composite materials for tissue replacement. Biomaterials 24: 2133 2151.

Wiedmann-Al-Ahmad M, Gutwald R N, Gellirich C, Ubner UH, Schmelzeisen R (2005) Search for ideal biomaterials to cultivate human osteoblast-like cells for reconstructive surgery. J Mat Sci 16: 57-66.

Yamada Y, Ueda M, Naiki T, Nagasaka T (2004) Tissueengineered injectable Bone regeneration for osseointegrated dental implants. Clin Oral Implants Res 15: $589-597$.

Yamaguchi DT, Kleeman CR, Muallem S (1987) Protein kinase $\mathrm{C}$-activated calcium channel in osteoblastlike clonal osteosarcoma cell line UMR-106. J Biol Chem 262: 14967-14973.

Zietek M, Gedrange T, Mikulewicz M (2008) Long term evaluation of biomaterial application in surgical treatment of periodontosis. J Physiol Pharmacol 59: 8186.

\section{Discussion with Reviewers}

Reviewer I: The last experiment of this paper is the most interesting. How could we explain that cells grown on top of Bio-Oss respond to PTH and CT whereas cells grown on plastic do not? What can be the role of the mineralized ECM from Bio-Oss in the elevated intracellular calcium levels upon treatment with PTH or CT? What other signalling pathway can be modulated in these conditions? Authors: That cells grown on top of Bio-Oss respond to PTH and CT whereas cells grown on plastic do not, is due to the fact that Bio-Oss is an osteogenic inductor. The signalling pathway and the role of PHT and CT are the subject of current experiments in our laboratory.

Reviewer II: Previous work by other authors failed at demonstrating any level of osteocalcin after association of cells with Bio-Oss in vitro. Did you try to detect this gene/protein? Can we conclude that Bio-Oss is a good inducer of $\mathrm{OB}$ differentiation when the terminal differentiation marker is missing? The authors conclude that Bio-Oss is "an excellent support for tissue reconstruction due to their biological characteristic and their ability to support the growth and the differentiation". However, several papers comparing Bio-Oss with other materials have already shown that Bio-Oss is a poor inducer of both cell proliferation and differentiation at least in vitro (e.g., Schmitt et al., 2008, Turhani et al., 2005). Please comment!

Authors: In our work, the osteocalcin level was estimated using the immunoassay test in the supernatant of either differentiated NHOst incubated with GBO and basal NHOst, while Western blot analysis was used to evaluate bone tissue-specific proteins like BSP, OPN, and collagen type I. The results obtained support the role of the BioOss as inducer of OB differentiation.

Moreover, in accordance with Wiedmann-Al-Ahmad et al. (2005), we believed that one reason for the different results obtained by other authors (Schmitt et al., 2008; Turhani et al., 2005) could be the source of the cells that could develop a different growth behaviour, and another reason could be the different culture conditions (e.g., seeding density, duration of cultivation, culture medium, inductive medium). 